\title{
Autotematyczna refleksja w intertekstualnym dialogu. Heretyckie telegramy Sándora Kányádiego w kontekście twórczości Zbigniewa Herberta
}

\author{
Abstract \\ Autothematic Reflection in Intertextual Dialogue. Heretic Telegrams \\ by Sándor Kányádi in the Context of Zbigniew Herbert's Output
}

Sándor Kányadi in his poetic cycle Heretic Telegrams enters into an intertextual dialogue with Zbigniew Herbert's output. This article attempts to interpret those poems which contain an autothematic reflection on literary creation, artistic expression, ways of narrating or the role of a poet in shaping collective consciousness. Kányádi establishes the opposition of fable and novel, presenting them as literary genres belonging to separate traditions, based on different perceptual patterns. These theses are accompanied by direct allusions to Zbigniew Herbert's works, what naturally leads to the adoption of comparative literary methods.

Keywords: Sándor Kányádi, Zbigniew Herbert, Heretic Telegrams, Mise en abyme, intertextuality

Słowa kluczowe: Sándor Kányádi, Zbigniew Herbert, Heretyckie telegramy, autotematyzm, intertekstualność

W świadomości publiczności literackiej na Węgrzech Zbigniew Herbert zaistniał po raz pierwszy dzięki poświęconemu powstaniu 1956 roku wierszowi o incipicie ***Stoimy na granicy, którego pierwotny tytuł Wegrom został wykreślony przez cenzora. Z prawdziwie szerokim zainteresowaniem spotkał się tam jednak dopiero tom esejów Barbarzyńca w ogrodzie, którego lektura natchnęła poetę László Nagya do przetłumaczenia wierszy polskiego poety ${ }^{1}$. Zetknięcie z dziełami Her-

\footnotetext{
1 Wiersze Zbigniewa Herberta w przekładzie László Nagya ukazały się wyborze Az angyal kihallgatása w 1979 roku.
} 
berta stanowiło twórczą inspirację także dla innego giganta węgierskiej literatury, Sándora Kányádiego. Przeczytawszy wydany w 1998 roku wybór wierszy $A z$ izlés hatalma (Potęga smaku), węgierski bard postanowił napisać cykl poetycki Heretyckie telegramy, odnoszący się wprost do spuścizny Herberta. Kányádi w swoich lirykach nie tylko przedstawia własne przekonania artystyczne, ale również zestawia je z poglądami na temat tworzenia, które znajdujemy u autora Pana Cogito. Niektóre z tych utworów wyróżnia zatem ścisłe połączenie autotematyzmu z bezpośredniością intertekstualnych odniesień. Heretyckie telegramy zostały napisane już po śmierci Herberta; swój literacki dialog Kányádi opiera jednak nie tylko na własnej interpretacji dostępnych mu w tłumaczeniu tekstów, ale także na osobistej rozmowie, do jakiej dekadę wcześniej doszło między poetami.

\title{
Alchemia słowa
}

Zbigniew Herbert jako częsty bywalec festiwali literackich miał okazję zetknąć się z wieloma wybitnymi pisarzami. Jednym z nich był właśnie węgierski poeta pochodzący z Transylwanii - Sándor Kányádi. Spotkanie literatów nastąpiło w roku 1988 w Rotterdamie, gdzie natychmiast zawiązała się między nimi nić porozumienia i doszło do szczególnego rozpoznania, „niczym między dwoma złodziejami”, jak to ujął w jednym z wywiadów Siedmiogrodzianin ${ }^{2}$. Wydarzeniu temu został poświęcony pierwszy z wierszy cyklu, zatytułowany Spotkanie, noszący, oczywistą dla osób znających kontekst powstania utworu, dedykację: $P a-$ mięci Zbigniewa Herberta. Otrzymawszy wiadomość o śmierci Polaka, Kányádi poczuł potrzebę upamiętnienia znajomości poprzez zdanie relacji z ich wspólnej rozmowy, której przebieg został nakreślony w poetyckiej formie:

\author{
Z panem Cogito w Rotterdamie \\ siedząc w najdalszym rzędzie \\ amfiteatru-azylu oglądaliśmy \\ słuchaliśmy i oczywiście oklaskiwaliśmy \\ nowohebrajskich poetów \\ potem niemal jednocześnie \\ w przerwie między dwoma wierszami \\ pochyliliśmy się ku sobie \\ odnowiliśmy sobie piękny język \\ piękny dla was \\ naprawdę piękny \\ choć to właściwie (mówiliśmy \\ wykorzystując następną pauzę) \\ wiersz daje językowi \\ piękno \\ i odwrotnie powiedział \\ albo powiedziałem po kolejnym
}

2 "I had met him at that international poetry festival in Rotterdam in 1988, and we immediately connected, like two thieves who recognize each other". P. Sohar, An Interview with Sándor Kányadi, http://calquezine.blogspot.com/2007/01/interview-with-sndor-knyadi.html (dostęp: 30.01.2020). 
żydowskim wierszu prawda że wiersz

jest pomnikiem języka

i budzicielem

naszego ciągłego poczucia braku

tego poczucia

które mogło dręczyć Najwyższego

w siódmym dniu gdy uświadomił sobie

zauważalną gdzieniegdzie w jego dziele

niedoskonałość

(...)

Bóg funkcjonuje cudownie

przez swego ducha świętego każdemu narodowi

objawia się w jego języku

bo każdy naród człowieczy

tylko we własnym języku może się wykształcić3

Wiersz ten w nietypowy sposób łączy z sobą lirykę okolicznościową o charakterze wspomnieniowym $\mathrm{z}$ autotematycznymi rozważaniami nad twórczością poetycką per se oraz z fillozoficzną, czy wręcz teologiczną, refleksją nad procesem krystalizowania się narodów. Poetom w trakcie rozmowy udało się uzgodnić bardzo konkretną wizję wspólnoty międzyludzkiej ufundowanej na językowej odrębności w ramach wciąż aprobowanej kultury uniwersalnej, w tym przypad$\mathrm{ku}$ - judeochrześcijańskiej. Mowa rodzima ma zatem wymiar dwojaki: z jednej strony stanowi o unikatowości określonej zbiorowości, umiejscawiając ją w danej lokalności, z drugiej jej regułami kieruje jakaś ogólniejsza zasada otwierająca wspólnotę na rozpościerające się poza jej opłotkami przestrzenie intelektualne i duchowe, które w procesie językowego przyswojenia podlegają internalizacji, modyfikując w ten sposób wyjściową tożsamość. Taką rolę omawiani tu pisarze przypisują Biblii.

Sándor Kányádi i Zbigniew Herbert starają się przeforsować koncepcję narodu, którą można nazwać narracyjną. Zakłada ona prymarną rolę opowieści, takiej czy innej mitologii, w procesie formowania się i krzepnięcia wielkich społecznych struktur. Uwidacznia się tu sprawcza moc słowa wynikająca ze współgrania poetyckiej oraz magicznej funkcji języka. Na plan pierwszy wysuwa się więc postać wieszcza, natchnionego szamana, pośrednika między ludem a Absolutem, przekuwającego wyrazy w idee oddziałujące na rzeczywistość społeczną.

Poeta, pozornie posiadający demiurgiczne artefakty, tworzy wiersz, który jest „pomnikiem języka”, ale również „,budzicielem/ naszego ciągłego poczucia braku (...) które mogło dręczyć Najwyższego/ w siódmym dniu gdy uświadomił sobie/ zauważalną gdzieniegdzie w jego dziele/ niedoskonałość". Autor występuje tu jednak nie tyle jako rywal Boga, samodzielny aktor mający czelność ulepszania ułomnego świata, ile jako wyraziciel woli Stwórcy, narzędzie w jego rękach. Zdaniem Kányádiego to nie poeta przemawia przez swoje wiersze, ale eksplicytnie tu wskazany Duch Święty. Pisarz nie panuje w pełni nad tworzywem, które przy-

3 S. Kányádi, Spotkanie [w:] Strażnik pamięci w czasach amnezji. Węrzy o Herbercie, Warszawa 2008, s. 13-14. 
biera ostatecznie nie do końca zamierzone kształty. Jako że z nieodgadnionego porządku języka wyłaniają się treści zaskakująco spójne, jak ideologie narodowe, pojawia się podejrzenie boskiej ingerencji. Takie spojrzenie na sztukę poetycką w żadnym razie nie degraduje pisarza do roli kopisty czy wręcz ubezwłasnowolnionej marionetki, ale umiejscawia go na pozycji kapłana, co tłumaczy powstanie romantycznego mitu wieszcza. Wizja ta współgra ze spostrzeżeniem Kanta: „Twórca, który dzieło zawdzięcza swej genialności, sam nie wie, skąd się biorą u niego idee do tego dzieła i nie jest też $\mathrm{w}$ jego mocy tego rodzaju idee dowolnie czy planowo wymyślać" ${ }^{4}$. Problem wymykania się tekstu ludzkiej intencjonalności ma zresztą długie tradycje filozoficzne, czemu Derek Attridge poświęca jeden z rozdziałów swojej książki Jednostkowość literatury. Stwierdzając istnienie owego fenomenu, zdecydowanie przeciwstawia się jednak przyznawaniu mu boskiej proweniencji:

To alternatywne rozumienie „tworzenia innego” nie powinno być traktowane jako mistyczna wiara w jakiegoś zewnętrznego aktora; wskazuje ono raczej, że relacja między stworzonym dziełem i świadomym aktem tworzenia nie jest wyłącznie relacją skutku i przyczyny. Pojawienie się czegoś całkowicie nowego wymaga pewnej rezygnacji z intelektualnej kontroli, a „to, co inne”, jest jedną z możliwych nazw tego, czemu oddaje się kontrolę, niezależnie od tego, czy jest to pojmowane jako coś „na zewnątrz”, czy „wewnątrz” podmiotus.

Ciekawe, że niezależnie od zaistnienia przesłanek religijnych bądź ich braku na pierwszy plan wysuwa się kwestia samoświadomości pisarza, ograniczonego systemem języka i własnym doświadczeniem, ale wraz z aktem konceptualizacji pośredniczącego w bieżącym przekazywaniu treści tworzonych niejako poza pierwotną intencją, wykraczających ponad autorskie zamierzenia.

\section{Anioł w smokingu, czyli oryginalność w dobie globalizacji}

Luźny sonet Sándora Kányádiego jest poprzedzony mottem z wiersza Herberta. Siódmy anioł to utwór oparty na symbolice siódemki, w kulturze judeochrześcijańskiej oznaczającej pełnię i doskonałość, wyrażającej się chociażby w liczbie archaniołów. Polski poeta jednak tylko częściowo odwołuje się do tej tradycji, wzbogacając poczet angelologiczny o dodatkowe byty duchowe, a rezygnując z innych. Jak zauważa Władysław Panas: „trzej Herbertowscy aniołowie - Azrafael, Dedrael i Szemkel - nie figurują w rejestrach żadnej z istniejących dotąd angelologii. Nie notują ich także - sprawdzamy jeszcze i ten wariant - katalogi demonologiczne. Ich imiona są zatem bezdyskusyjnie dziełem poety”.6. Szemkel, czyli tytułowy „siódmy anioł”, wyraźnie odstaje od reszty:

Siódmy anioł

jest zupełnie inny

nazywa się nawet inaczej

(...)

4 I. Kant, Krytyka władzy sądzenia, Warszawa 1964, s. 232.

5 D. Attridge, Tworzenie i inny [w:] idem, Jednostkowość literatury, Kraków 2007, s. 43.

6 W. Panas, Tajemnica siódmego anioła: cztery interpretacje, Lublin 2005, s. 14. 
jest czarny i nerwowy

i był wielokrotnie karany

za przemyt grzeszników

między otchłanią

a niebem? .

Jego winą jest współczucie, które czyni go odmiennym. Znajduje ono ujście w postępkach niejednoznacznych moralnie. Mimo groźby ostracyzmu czarny anioł służy jednak celom, które uważa za słuszne. Okazuje się, że poniesione ryzyko ostatecznie nie przynosi mu zguby:

malarze bizantyńscy

kiedy malują siedmiu

odtwarzają Szemkela

podobnego do tamtych

sądzą bowiem

że popadliby w herezję

gdyby wymalowali go

takim jak jest

czarny nerwowy

w starej wyleniałej aureoli ${ }^{8}$.

Twórcy wizerunków obawiają się popełnienia herezji, przed którą nie wzdragał się sam Szemkel. Nie wzbraniał się przed nią także Kányádi, solidaryzując się z Herbertem i pisząc Heretyckie telegramy.

W wierszu Transylwańczyka funkcję przewrotnego odszczepieńca pełni właśnie postać autora Siódmego anioła. Pozostając wierny tradycji kultury, wdziewa smoking, zakłada muszkę czy też krawat, wsuwa wypolerowane lakierki, traktując swój ubiór jako widomy znak poszanowania wypracowanych przez stulecia konwencji. I tak wyraz lojalności i przywiązania do zastanych norm społecznych staje się manifestacją własnej jednostkowości w czasach po upadku dawnych kanonów. Poeta wyraźnie odstający, niemieszczący się w dominującym paradygmacie jest tu sakralizowany poprzez przyrównanie do wspomnianego archanioła, jednak to wywyższenie skutkuje niebezpiecznym, alienującym go z thumu przeciwstawieniem zunifikowanej masie ludzkiej:

i z uśmiechem archanioła patrzył w przestrzeń ponad hordami dżinsowych światowych poetów ${ }^{9}$.

Owa wielość jest tu rozumiana zdecydowanie pejoratywnie. „Ja” liryczne nie dostrzega poszczególnych jednostek, ale jedynie zgromadzenie zuniformizowanych, choć silących się na oryginalność, wierszokletów.

Globalizacja - zdaje się sugerować Kányádi - de facto uniemożliwia autoekspresję, bez której nie ma prawdziwego spotkania dwóch osób. To właśnie zetknięcie konkretnych lokalności, których emanacją jest chociażby język naro-

\footnotetext{
7 Z. Herbert, Siódmy aniol [w:] idem, Wiersze zebrane, Kraków 2008, s. 127.

8 Ibid., s. 128.

9 S. Kányádi, Luźny sonet [w:] Strażnik pamięci..., s. 17.
} 
dowy, o czym czytamy w pierwszym wierszu cyklu, otwiera drogę do dialogu i faktycznego porozumienia, swego rodzaju uniwersalizmu. Gdy nieznane są pozycje, z których zabiera głos jedna ze stron rozmowy, druga nie potrafi zająć stanowiska, odnaleźć w postawie Innego podobieństw ani dociec proweniencji różnic.

\title{
Między bajką a powieścią: spór tradycji z nowoczesnością
}

Jednym z istotniejszych wątków cyklu, przewijającym się przez kilka wierszy, jest rola języka w kształtowaniu relacji międzyludzkich i rzeczywistości społecznej. Krótki liryk Bajka o powieści koncentruje się natomiast w głównej mierze na narracyjnym koncepcie życia, zarówno indywidualnego, jak i jego archetypowej reprezentacji fabularnej (bajka, mit), genologicznie ewoluującej do opowieści roszczącej sobie pretensje do drobiazgowego i sumarycznego ujęcia świata przedstawionego (powieść):

\author{
razem z nami rosną rozwijają się bajki \\ $\mathrm{z}$ biegiem czasu rozrastają się $\mathrm{w}$ powieść \\ każda szanująca się powieść jest właściwie \\ nadmiernie skomplikowaną upstrzoną \\ uwagami reżysera smutnie kończącą się bajką \\ w której dobro nie zyskuje godnej nagrody \\ a zło zasłużonej kary \\ ukradkiem przecież wracamy do bajek \\ każdy jednak tak chciałby porzucić \\ swoją powieść tak by pragnął przynajmniej tego \\ że jeśli dobry ma nie zaznać dobra to niechby zły nie uniknął \\ dobrze zasłużonej doczesnej kary ${ }^{10}$.
}

Tak widziana powieść, ze względu na stłoczenie realistycznego konkretu, mnogość uwag narratora, brak jednoznacznego morału i pokrzepiającego serce zakończenia, okazuje się bajką zdegenerowaną, bo tracącą swoje alegoryczno-paraboliczne właściwości. Sándor Kányádi stoi na stanowisku, że istnieje wyraźna potrzeba wizji świata poukładanego, opartego na jasnych i koherentnych pryncypiach, zapobiegających społecznym anomiom.

Zapis okazale skomplikowanej egzystencji, w którym siedmiogrodzki poeta upatruje zagrożenia dla ładu powszechnego i rudymentarnego poczucia sprawiedliwości, inni postrzegają jako remedium na zniewolenie jednostki. Pierwszorzędny powieściopisarz Orhan Pamuk dostrzega w nim zbawienną szansę na uzyskanie własnej podmiotowości i prawa do samostanowienia:

Nauczyłem się traktować życie poważnie dzięki temu, że w młodości traktowałem poważnie powieści. Powieści udowadniają bowiem, że mamy wpływ na wydarzenia, a dokonywane wybory rozstrzygają o naszym losie. (...) Gdy porzucamy tradycyjne gatunki epickie i zaczynamy czytać powieści, dochodzimy do wniosku, że nasz świat i podejmowane przez nas decyzje mogą być równie ważne jak posunięcia królów, paszów, armii, rządów i bo-

10 S. Kányádi, Bajka o powieści [w:] Strażnik pamięci..., s. 17-18. 
gów oraz wydarzenia historyczne czy wojny, a nasze doznania i myśli nawet ciekawsze od nich. Pochłaniając w młodości powieści, czułem zapierającą dech w piersi swobodę i wiarę w siebie $^{11}$.

Obfitość przeżyć i doznań jest w wykładzie Pamuka afirmowana także dlatego, że pozwala na ukazanie ludzkich rozterek bez przesadnego ich upraszczania. Powieść, choć wyrasta z tradycji bajki, baśni i innych zbliżonych im form narracyjnych, traci wszelako swój rys parenetyczny. Dystans, z jakim czytelnik ma do czynienia w przypadku bajki, pozwala na dokonywanie jednoznacznych ocen moralnych. Celem nowoczesnych opowieści jest jednak wtargnięcie w życie poszczególnego człowieka uniemożliwiające beznamiętny osąd:

Baśnie (...) przeważnie opisują rzeczywistość z punktu widzenia czytelnika. Bohater umieszczony jest zwykle w scenerii, na którą czytelnicy patrzą z zewnątrz. Powieść tymczasem zaprasza nas do wejścia w jej świat. Postrzegamy go z punktu widzenia bohatera: przez jego doznania i, gdy to możliwe, przez jego słowa. (...) Świat powieściowy widziany oczyma bohaterów wydaje się bliższy i bardziej zrozumiały - literatura zawdzięcza swoją nieodpartą siłę właśnie temu poczuciu bliskości ${ }^{12}$.

Sándor Kányádi i Orhan Pamuk, mimo że reprezentują stanowiska przeciwstawne, zgadzają się w jednym: to właśnie narracja, tak czy inaczej zorganizowana opowieść, wprowadza w życie człowieka pierwiastek refleksji etycznej, pozwalający na dokonywanie moralnych wyborów. Paul Ricœur w książce $O$ sobie samym jako innym, rozważając relacje między tożsamością osobową a narracyjną, tak odnosi się do tej kwestii: „,działania zorganizowane w opowieść dają się opracować tematycznie dopiero w ramach etyki”. Dalej pisze jeszcze dobitniej: „nie ma opowieści obojętnej etycznie. Literatura jest wielkim laboratorium, w którym wypróbowuje się wartościowania, oceny, sądy uznania i potępienia, dzięki czemu narracyjność pełni rolę wprowadzenia do etyki"13. Różnica w nastawieniu do konkretnych gatunków, w przypadku wyżej wymienionych twórców, wynika z przeświadczeń natury ogólnej. Kányádi, jako pisarz poniekąd religijny, jest przekonany o istnieniu prawa boskiego, to jest uniwersalnego kodeksu norm i zachowań, niezależnego od kulturowych i jednostkowych uwarunkowań. Literatura w tej perspektywie zostaje ograniczona do roli przekaźnika tychże przykazań („Bóg funkcjonuje cudownie/ przez swego ducha świętego każdemu narodowi/ objawia się w jego języku (...) Duch Święty jest najdawniejszym Comeniusem"14). Pełni zatem przede wszystkim funkcję edukacyjną poprzez odzwierciedlanie już istniejących wzorców, podczas gdy inne jej walory okazują się wtórne. Pamuk uważa natomiast, że wszelkie wartości są wypracowywane w trakcie lektury przez umysł samego czytelnika; nie mają one jednak żadnego metafizycznego punktu odniesienia. W obu przypadkach na plan pierwszy wysuwa się więc etyczny aspekt opowieści. Można w uproszczeniu powiedzieć, iż odmienne są jedynie metody pedagogiczne, jakimi charakteryzują się poszczególne gatunki literackie. Bajka

\footnotetext{
11 O. Pamuk, Pisarz naiwny i sentymentalny, Kraków 2012, s. 57.

2 Tamże, s. 57-58.

3 P. Ricœur, O sobie samym jako innym, Warszawa 2003, s. 191-192.

14 S. Kányádi, Spotkanie..., s. 13-14.
} 
reprezentowana przez Kányádiego należałaby do prostej w wymowie literatury parenetycznej, a uprawiana przez Pamuka powieść to już zdecydowanie przykład wyrafinowanej heurezy. W praktyce zastosowanie różnych narzędzi przynosi na ogół odmienne rezultaty; powstają kolidujące z sobą wizje świata.

Zdaniem Kányádiego atutem bajki jest jej przewidywalność, którą zawdzięcza swojej prostocie i powtarzalności motywów. Tę ich właściwość celnie opisuje Northrop Frye:

Bajki ludowe stanowią po prostu abstrakcyjne wzorce opowieści, nieskomplikowane
i łatwe do zapamiętania, równie nieskrępowane barierami językowymi i kulturowymi jak
wędrowne ptaki barierami celnymi, złożone z wymiennych motywów, które można poli-
czyć i skatalogować. (...) Bajka ludowa interesuje pisarzy z tych samych powodów, dla
których martwa natura interesuje malarzy - ponieważ ilustruje podstawowe zasady narra-
cyjne. Przed autorem, który się nią posługuje, staje techniczny problem nadania jej pozo-
rów prawdopodobieństwa i wiarygodności, które byłyby do przyjęcia dla wyrafinowanych
odbiorców. Kiedy mu się to udaje, powstaje nie realizm, lecz zniekształcenie realizmu,
dokonane ze względu na strukturę. Takie zniekształcenie jest literackim odpowiednikiem
redukowania przedmiotu do formy geometrycznej w malarstwie ${ }^{15}$.

Bajka, zbudowana - jak dowiódł Władimir Propp - wedle określonych modeli narracyjnych, czyli na bazie istniejących struktur fabularnych („bajka, jak każdy żywy organizm, tworzy byty podobne do niej samej"'16), szerzy przekonanie o istnieniu porządku moralnego determinującego ludzką egzystencję. Dostrzeżenie w rozbudowanej opowieści zagrożenia problematyzacją ludzkiego losu, a w konsekwencji relatywizacją zastanych wartości, zdaje się typową reakcją tradycjonalisty. Umieszczenie tego właśnie wiersza, zawierającego refleksję o naturze ogólnej, pośród innych, nawiązujących do konkretnych wydarzeń i osób, a przede wszystkim do postaci Zbigniewa Herberta, nie jest naturalnie przypadkowe. Polski poeta był bowiem także twórcą krótkich bajek ${ }^{17}$, co zgodnie z wymową utworu miałoby go stawiać w gronie twardych obrońców odziedziczonego ładu. Można postawić tezę, że tym sposobem Kányádi zabiera głos w dyskusji o stosunku Herberta do tradycji, umieszczając go wśród klasyków i samemu dołączając do tego grona.

Siedmiogrodzki poeta ma pełną świadomość, że to powieść jako wykwit określonej formacji kulturowej znajduje się u szczytu potęgi i popularności, stąd też w jego wierszu jest obecna wyraźna nuta rozgoryczenia, melancholii oraz niezgody: „każdy jednak tak chciałby porzucić/ swoją powieść tak by pragnął przynajmniej tego/ że jeśli dobry ma nie zaznać dobra to niechby zły nie uniknął/ dobrze zasłużonej kary". Jest to oczywiście aluzja do Przesłania Pana Cogito, w którym padają słowa: ,powtarzaj stare zaklęcia ludzkości bajki i legendy/ bo tak zdobędziesz dobro którego nie zdobędziesz (...) a nagrodzą cię za to tym co mają pod ręką/ chłostą śmiechu zabójstwem na śmietniku”, a także: „a Gniew twój bezsilny niech będzie jak morze”, „niech nie opuszcza ciebie twoja siostra

15 N. Frye, Mit, fikcja i przemieszczenie [w:] Studia z teorii literatury. Archiwum przekładów „Pamiętnika Literackiego”, Wrocław 1977, t. 1, s. 295-296.

16 W. Propp, Morfologia bajki, „Pamiętnik Literacki” 1968, z. 4, s. 218.

17 Por. Z. Herbert, Bajki, Kraków 2009. 
Pogarda” oraz ,i nie przebaczaj zaiste nie w twojej mocy/ przebaczać w imieniu tych których zdradzono o świcie" ${ }^{18}$. Afirmacja prostych rozstrzygnięć moralnych (dokonywanych przez bohaterów bajek czy eposów rycerskich), znana chociażby z wiersza Kolatka (suchy poemat moralisty/tak - tak/nie - nie $e^{19}$ ), u Herberta nie idzie jednak w parze $\mathrm{z}$ otwartą, eksplicytnie wyrażoną krytyką nowoczesnych wzorców percepcyjnych. Próba wskrzeszenia tradycyjnych wartości nie przekreśla dorobku ostatnich pokoleń. W tekście Poeta wobec wspótczesności pojawia się postulat pozaczasowości dzieła sztuki jako owocu doświadczenia tu i teraz, co wprawdzie stanowi zdystansowanie się od wizji działalności artystycznej jako aktywności stricte politycznej, ale nie jest ucieczką w czysty estetyzm ani tym bardziej prostolinijny epigonizm:

Sferą działalności poety, jeśli ma on poważny stosunek do swojej pracy, nie jest współczesność, przez którą rozumiem aktualny stan wiedzy społeczno-politycznej i naukowej - ale rzeczywistość, uparty dialog człowieka z otaczającą go rzeczywistością konkretną, z tym stołkiem, z tym bliźnim, z tą porą dnia, kultywowanie zanikającej umiejętności kontemplacji. A przede wszystkim - budowanie wartości, budowanie tablic wartości, ustalanie ich hierarchii, to znaczy świadomy, moralny ich wybór z wszystkimi życiowymi i artystycznymi konsekwencjami, jakie z tym są związane - to wydaje mi się podstawową i najważniejszą funkcją kultury ${ }^{20}$.

Tak widziana kultura jest zatem nie tyle jakąś pieczęcią czy matrycą, która wypala swoje piętno na każdym, kto znalazł się w jej zasięgu, ile raczej zbiorem odpowiedzi, których musi udzielić jednostka, usiłując ustalić swoje relacje ze światem. To domeną Kányádiego jest tu nieco bezrefleksyjny tradycjonalizm, a jego imputowanie Herbertowi, który po Bloomowsku starał się przepracowywać i reinterpretować skostniałe konwencje, by tchnąć w nie nowe życie, wydaje się nadużyciem, nawet jeśli gros wyznawanych wartości niniejsi poeci podzielali.

\section{Poetycki manifest}

Rozmowę przeprowadzoną w Rotterdamie Sándor Kányádi, w swoim wierszu Wspólny komunikat, nazywa „spotkaniem na wysokim szczeblu”. Miało wówczas dojść do ustalenia przez interlokutorów stanowiska w kwestii roli poezji w życiu jej twórców i społeczeństw. Za sprawą autotematyzmu utwór przybiera charakter quasi-manifestu, wobec czego odpowiedzialni za jego powstanie prominentni przedstawiciele bractwa poetów jawią się w pewnym sensie jako reprezentanci, jeśli nie grupy literackiej, to przynajmniej pokolenia spojonego jednakim światopoglądem artystycznym. Kolegialność zapatrywań prezentowanych w wierszu koliduje jednak na zasadzie paradoksu z ich treścią:

Zgodziliśmy się że poezja tak jak miłość jest sprawą osobistą każdego człowieka²1.

18 Z. Herbert, Przestanie Pana Cogito [w:] idem, Wiersze zebrane ..., s. 439-440.

19 Z. Herbert, Kolatka [w:] idem, Wiersze zebrane..., s. 103.

20 Z. Herbert, Poeta wobec wspótczesności [w:] idem, Węzet gordyjski oraz inne pisma rozproszone 1948-1998, Warszawa 2001, s. 45.

21 S. Kányádi, Wspólny komunikat [w:] Strażnik pamięci..., s. 23. 
Poezja, podobnie jak miłość, jest przeżywana - twierdzą autorzy komunikatu - przez każdego w sposób indywidualny. Oznacza to, że obcowanie z nią polega przede wszystkim na indywidualnej lekturze, niezależnej od doświadczeń czytelniczych innych ludzi. Ponadto służy ona wyartykułowaniu przez autora potrzeby bliskości, nawiązania więzi z drugim człowiekiem; jest zatem wyrazem osamotnienia i próbą przekroczenia tego stanu. Mimo że za naczelny i prymarny cel poezji zostaje tu uznana komunikatywność, a więc skuteczne dotarcie z przekazem do odbiorców, nie zawsze liryczne wynurzenia znajdują oczekiwany odzew, z czym ich autor musi się pogodzić i twórczo ten fakt wykorzystać:

nikt nie może wymagać od tego kogo kocha odwzajemnienia miłości
miłość odwzajemniona to przypadek radosny a nawet szczęśliwy
ale powszechnie
wiadomo że z miłości nieszczęśliwych zwłaszcza z nieszczęśliwych
też rodzą się
dzieła o katartycznej sile nikt nikogo nie zmusza do poświęcenia się poezji²2.

Zakon poetów składa się z eremitów, którzy przecież nie ze wsobnej mizantropii żyją w odosobnieniu. Ich losy zostały bowiem z góry zapisane w księdze kondycji ludzkiej. Wiodą swój żywot wedle współdzielonej reguły, na ogół pokornie przyjmując niezawinione cierpienie, które - tę Herbertowską konstatację zdaje się przejmować Kányádi - ma wymiar uniwersalny, a przez to pozwalający na przezwyciężenie alienacji.

Polak i Siedmiogrodzianin tkwią w tradycyjnym romantycznym paradygmacie, sytuując poetę w centrum zainteresowania narodu, który raz żywo wsłuchuje się w głos wieszcza, innym razem strąca go w niebyt, by ostatecznie przywrócić należne mu miejsce w panteonie:

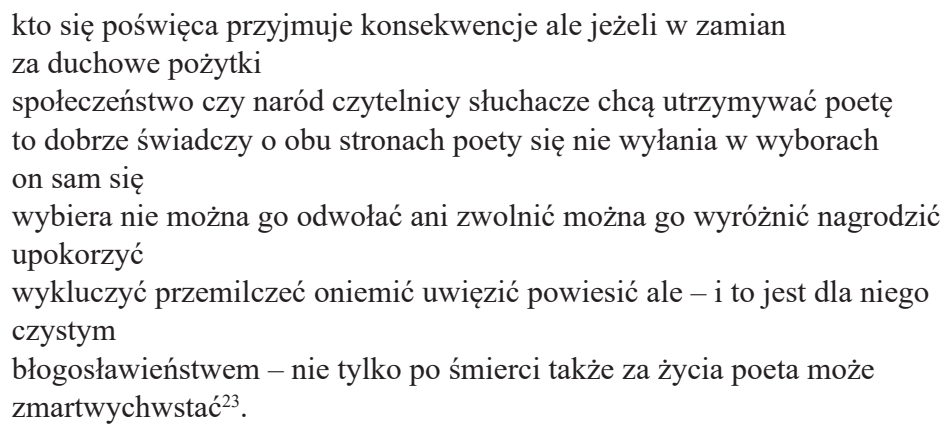

Jako nosicielowi doniosłych uczuć i abstrakcyjnych idei („nieusuwalny najemnik miłości dozgonny dłużnik języka”) poecie przynależne są atrybuty duchowego przywódcy, świadomego jednakże swoich niedoskonałości, zbliżających go do grona podobnie ułomnych, choć mniej egzaltowanych, pobratymców (,w cielesnym swym/ bycie dokładnie tak samo słaby chorowity kruchy podatny na zepsucie/ i chyba nieznośniejszy niż większość jego bliźnich...”), co pozwala mu uniknąć grzechu pychy (,stale z siebie niezadowolony”), przed którym prze-

\footnotetext{
22 Ibid.

23 Ibid.
} 
strzegał Pan Cogito w swoim Przesłaniu (,strzeż się jednak dumy niepotrzebnej/ oglądaj w lustrze swą błazeńską twarz/ powtarzaj: zostałem powołany - czyż nie było lepszych").

W świetle tych analiz cykl poetycki Sándora Kányádiego jawi się jako kolejny głos posługujący się narodowym dyskursem w celu wykorzystywania spuścizny Zbigniewa Herberta do mitotwórczego kultywowania polsko-węgierskiego braterstwa. Odnajdujemy w nim jednak również przenikliwą refleksję nad dorobkiem literackim Polaka, pomimo faktu, że węgierski poeta swoje mniemania opierał na znajomości jedynie wyrywków tej twórczości dostępnych w jego rodzimym języku oraz na jednorazowym spotkaniu z ich autorem.

Autotematyzm stanowi jedno z kluczowych zagadnień poruszanych w owym cyklu. Ze względu na czas powstania utworów, niedługo po śmierci Zbigniewa Herberta, kiedy sam Kányádi był już zaawansowany wiekiem, można doszukiwać się w nich elementu artystycznego credo i chęci podsumowania swojej życiowej roli poety.

\section{Bibliografia podmiotowa}

Herbert Z., Az angyal kihallgatása, Budapest 1979.

Herbert Z., Az izlés hatalma, Budapest 1998.

Herbert Z., Bajki, Kraków 2009.

Herbert Z., Wiersze zebrane, Kraków 2008.

Herbert Z., Węzeł gordyjski oraz inne pisma rozproszone 1948-1998, Warszawa 2001.

Kányádi S., Eretnek táviratok [w:] S. Kányádi, Felemás őszi versek, Pécs 2002.

Kányádi S., Heretyckie telegramy [w:] Strażnik pamięci w czasach amnezji. Węgrzy o Herbercie, red. Jerzy Snopek, Warszawa 2008.

\section{Bibliografia przedmiotowa}

Attridge D., Jednostkowość literatury, Kraków 2007.

Frye N., Mit, fikcja i przemieszczenie [w:] Studia z teorii literatury. Archiwum przekładów „Pamiętnika Literackiego”, Wrocław 1977, t. 1.

Herbert na językach. Współczesna recepcja twórczości Zbigniewa Herberta w Polsce i na świecie, red. A. Grabowski, J. Kopciński, J. Snopek, Warszawa 2010.

Herbert Środkowoeuropejczyk. Twórczość Zbigniewa Herberta w kontekstach $i$ kontaktach środkowoeuropejskich, red. K. Krasuski, Katowice 2011.

Język dalekosiężny. Przekłady i międzynarodowa recepcja twórczości Zbigniewa Herberta, red. M. Heydel, E. Wójcik-Leese, M. Woźniak, Kraków 2010.

Kant I., Krytyka władzy sądzenia, Warszawa 1964.

Márkus B., Pán Transsylvanicus (Kányádi Sándor: Felemás őszi versek), „Hitel” 2003, nr 2.

Nagy G., A szülőföld és az anyanyelv (A nemzeti önazonosság keretei Kányádi Sándor költészetében), „Forrás” 2004, nr 5. 
Pamuk O., Pisarz naiwny i sentymentalny, Kraków 2012.

Panas W., Tajemnica siódmego anioła: cztery interpretacje, Lublin 2005.

Pécsi Gy., Kányádi Sándor, Pozsony 2003.

Pomogáts B., Megtartó hagyomány [w:] B. Pomogáts, Kisebbség és humánum. Müértelmezések az erdélyi magyar irodalomból, Budapest 1998.

Propp W., Morfologia bajki, „Pamiętnik Literacki” 1968, z. 4.

Ricœur P., O sobie samym jako innym, Warszawa 2003.

Sohar P., An Interview with Sándor Kányadi, http://calquezine.blogspot.com/2007/01/ interview-with-sndor-knyadi.html (dostęp: 30.01.2020).

Strażnik pamięci w czasach amnezji. Węgrzy o Herbercie, red. J. Snopek, Warszawa 2008.

Vörös L., Kányádi Sándor. Egy monografia töredékei, Szeged 2009. 